\title{
Supply chain management of entrepreneurial competence through cultural orientation and cross cultural competence
}

\author{
Fajar Pasaribu ${ }^{a^{\star}}$, Tapi Rondang Ni Bulan ${ }^{\mathrm{b}}$, Ani Murwani Muhar ${ }^{\mathrm{b}}$ and Widia Astuty $^{\mathrm{a}}$
}

${ }^{a}$ Universitas Muhammadiyah Sumatera Utara, Indonesia

${ }^{b}$ Universitas Harapan Medan, Indonesia

A B S T R A C T

\begin{tabular}{l} 
Article history: \\
Received October 16, 2021 \\
Received in revised format \\
October 30,2021 \\
Accepted December 212021 \\
Available online \\
December 212021 \\
\hline Keywords: \\
Individual factors \\
External factors \\
Cross cultural orientation \\
Competence \\
SMEs
\end{tabular}

\begin{abstract}
This study aims to determine the effect of individual and external factors on cultural orientation and cross-cultural competence and their impact on the formation of entrepreneurial competence. The research is quantitative verification research. The analysis and observation unit of this research are SME entrepreneurs in the creative fashion industry in North Sumatra who have already carried out international business activities. The study involved 129 samples taken randomly from SME entrepreneurs in North Sumatra. Data were analyzed using partial least squares (PLS). From the results of this study, it is shown that individual factors and external factors can play a role in the formation of cultural orientation and cross-cultural competence of entrepreneurs. However, in the formation of entrepreneurial competencies, it is shown that only individual factors can have an influence on entrepreneurial competence. In addition, this study also found a direct relationship between cultural orientation and cross-cultural competence with entrepreneurial competence.
\end{abstract}

(C) 2022 Growing Science Ltd. All rights reserved.

\section{Introduction}

Micro, Small and Medium Enterprises (MSMEs) have an important role in the development and economic growth of a country. MSMEs provide the largest contribution to the formation or growth of gross domestic product (GDP) compared to the contribution of large businesses. A country's economy can develop through entrepreneurship. Entrepreneurship is able to create innovations that will ultimately build people's welfare with applied innovations. In the field of entrepreneurship, there are 5 aspects that are formed, namely entrepreneurship being able to introduce new products, introducing new methods, introducing new markets that are now following the flow of globalization, namely online transactions, introducing new materials, new compatibility and finally new organizations. The number of innovations that can be created from entrepreneurship will be able to support the economy. The establishment of a free trade area among ASEAN countries is one form of international trade. Communities classified in this area-free area are called the ASEAN Economic Community (AEC), which is a community or organization in the economic sector in ASEAN. The influence of the free market is most felt in the service sector, namely the HR sector. The need for quality human resources has become very high because of the intense competition in this era. Therefore, business actors as human resources in countries that are members of the community must be able to develop a global perspective on their business and at the same time anticipate cultural diversity in their business operations (Naisbitt, 2006). In creating innovation in entrepreneurship seen from several aspects, in creating an entrepreneurial model there are several important aspects that need to be described (Yuhua \& Bayhaqi, 2013), namely: MSMEs must be able to increase expertise in the field of technical and operational capabilities to participate as well as in the era of globalization, MSMEs must have sufficient capital to keep up with the ever-changing global flow, have superior human resources and be able to survive in business practices. This research focuses on entrepreneurship development and human resource capacity building. This issue has been discussed scientifically, among other things, some literature states that entrepreneurial development is determined by entrepreneurial competencies as relevant competencies for entrepreneurs. This competency is considered

* Corresponding author

E-mail address: fajarpasaribu.umsu@gmail.com (F. Pasaribu)

(C) 2022 Growing Science Ltd. All rights reserved.

doi: $10.5267 /$ j.uscm.2021.12.010 
to be an important step in preparing SMEs to achieve a sustainable competitive advantage because business in SMEs is very dependent on the ability of the owner (Sadler-Smith et al., 2003; Ulwan, 2021). In addition, entrepreneurial competence is a strong predictor of SME business success and entrepreneurship is very important for international social and economic well-being (Ahmad, 2007; Baum et al., 2007; Bukhori, 2021).

In managing business in the era of globalization, a cultural orientation is required. This is as stated by Hofstede (2010) that the cultural dimension offers several advantages to entrepreneurial behavior in understanding different cultural contexts and has a large impact on the economic health of a country by encouraging certain values that help or hinder growth in the economy. This cultural reference framework for cross-cultural entrepreneurial activities is also supported by Abbey (2002), Ahmad (2007), Sajilan \& Tehseen (2015) and Richter et al., (2016). North Sumatra is a city that has 355,502 entrepreneurs under the auspices of the North Sumatra Cooperatives and MSME Office (sumutprov.go.id. 26 October 2020). The results of interviews with several MSMEs in North Sumatra revealed that the cultural orientation in general business management has not been maximally carried out, there are global demands, inadequate technology and infrastructure, and the inadequate role of the government to support business management.

\section{Theoretical Review}

\subsection{Entrepreneurial competence}

Entrepreneurial competence is an ability that is specifically directed to develop relationships between companies related to specific activities that emphasize trust, values and top management activities that play a role in creating an organizational culture and fostering a variety of knowledge (Khalid \& Bhatti, 2015). Meanwhile, Bacigalupo et al. (2016) conducted a study of entrepreneurial competence for European Union Entrepreneurs, which defines entrepreneurial competencies for all areas of life. It builds on a broad definition of entrepreneurship and refers to value creation in the private, public and third sectors in each domain and value chain. The results showed that it is very important for entrepreneurs to develop certain competencies. Meanwhile, Neneh and Vanzyl (2012) adopted a theoretical framework on the long-term achievement of SMEs and empirically tested the validity that entrepreneurs who have all entrepreneurial competencies have a very high probability of achieving the survival of SMEs.

\subsection{Individual Factors}

Individual factors are unique personal characteristics and are the most valuable resources for outstanding company performance (Sajilan et al., 2015) Creative entrepreneurs/individuals who are equipped with an entrepreneurial and creativitybased mindset that allows transforming fundamental and creative input into marketable output with economic value (Protogerou et al., 2015). Individual characteristics can be seen from abilities, personal needs, beliefs, experiences, expectations, and others. For small and medium-sized companies, many of which have limitations in examining environmental conditions in detail, especially due to limited human resources and funding, environmental conditions and all changes can be observed based on the experience and understanding of company leaders in interacting with the environment. If these individual business actors must be able to compete, they must increase their entrepreneurial abilities. In the development of entrepreneurship, many factors are needed, but the most important thing is humans/individuals in this case entrepreneurs as superior human capital (Man et al., 2002; Hayton \& Kelley, 2006; Ahmad, 2007; Lampel \& Germain, 2016). In addition, it is proven that the suCCess of an entrepreneur will have an impact on the performance of his business (Sajilan et al., 2015).

\subsection{External Factors}

External factors are circumstances, conditions, situations, or the external environment of a company or entrepreneur (Welter, 2011). External factors are factors that have an important impact on SMEs in economic growth and job creation to face the need to change business models from the perspective of entrepreneurs and business opportunities (Lampela et al., 2014). Inglehat and Baker (2000) found empirical evidence that economic development can predict changes in culture and sociopolitical life. This impact causes businesses to require external factors related to entrepreneurial activities, such as initiativetaking, resource consolidation, management, relative autonomy and risk taking. The same thing was also examined by Lee (2018), who conducted research to understand the relationship between the unique characteristics of national culture and entrepreneurship and the forces of the economic environment, political/legal and social which will affect the level of entrepreneurship, and ultimately the global competitiveness of the nation. Then Man et al., (2002), state the lack of market power and the turbulent nature of the emerging markets faced by many SMEs, often making them more vulnerable to external influences than larger firms. While Kollmann et al. (2007) stated that entrepreneurial orientation is influenced by external factors, and this is necessary to develop individuals.

\subsection{Cultural Orientation}

Culture is the values held by a group/country. The use of culture is based on understanding, giving influence to a person where in carrying out something they still adhere to the cultural values they adhere to, so that culture colors the behavior of entrepreneurs in running a business. Culture penetrates all aspects of life, the business environment is colored by cultural differences, so that the ability to understand culture is important in the business world. Individuals, in this case are entrepreneurs, as actors of the business, are one of the factors that cause the failure/suCCess of a business. Hofstede (2016) states that culture 
and personality are interrelated but the relationship is statistical, there are various individual personalities in each national culture, but national cultural values should not be used to stereotype individuals. Rosillo-Díaz et al. (2019) states that certain cultural tendencies to produce entrepreneurs have resulted in the determinants of entrepreneurship appearing to be influenced by culture. Hull et al., (2007) who state that in the digital world, millions of people from various cultures and backgrounds interact every day. This situation makes the importance of culture a factor in the development of this concept of entrepreneurial digital competence.

\subsection{Cross cultural Competence}

Cross-cultural capabilities are closely related to entrepreneurial activities, where there is competition for free markets, competition for resources and competition in business. A strategy is needed to identify international opportunities and achieve suCCess, by creating cross-cultural capabilities for businesspeople (entrepreneurs) who will also shape their entrepreneurial abilities. Developing relevant competencies for entrepreneurs is an important step in preparing SMEs to achieve a sustainable competitive advantage. This is supported by the results of a study conducted by Muzychenko (2008), Knorr et al. (2013) and Alvarez and Urbano (2013).

\section{Research Methods}

This study uses a quantitative verification approach with a survey method, which is to collect data on objects in the field by taking a sample from a population using a questionnaire as the main data collection tool. The population in this study was taken from the database of the North Sumatra industry and trade service related to data on SMEs that carry out export activities/training throughout North Sumatra and from several agencies in North Sumatra province who participated in training in 2019 totaling 190 people. The sampling technique used the Slovin formula with a margin off error of 5\%. Based on this formula, a sample of 129 people was obtained. The sample is homogeneous, therefore the determination of the sample in this study uses Simple Random Sampling. There are two independent variables used, namely: individual factors (X1), external factors (X2), and one dependent variable entrepreneurial competence (Z) and two intervening variables, namely cultural orientation (Y1) and cross-cultural competence (Y2). The data analysis approach used in this study is Partial Least Square (PLS).

\section{Results}

\subsection{Outer Model Validation}

There are two types of validity tests in PLS, namely convergent validity and discriminant validity. Meanwhile, the reliability test used Cronbach's Alpha value and composite reliability. The following is the validity and reliability test for the intervariable linkage model from this study. The first is convergent validity. Convergent Validity is a method for testing construct validity. The construct validity of the indicators was assessed by examining each loading factor. From the data processing, it is known that almost all indicators measuring each construct have a value of $>0.50$, with a $\mathrm{p}$ value $<0.05$. The loading factor value of some indicators does have a value of less than 0.5 but it is statistically significant, because the t-value shows a value greater than 1.97 with a $95 \%$ confidence level and a $\mathrm{p}$ value $<0.05$ (Hair Jr et al., 2016). The CR value for all dimensions is $>$ 0.7. So that it confirms the validity of the construct, both dimensions and latent variables. The second is discriminant validity. Discriminant validity refers to the extent to which constructs actually differ from one another empirically. Discriminant validity in this study was evaluated using the Hetereter-Monotrait correlation ratio (HTMT). HTMT values close to 1 indicate a lack of discriminant validity. In this study, it is suggested that the threshold is 0.85 . If the HTMT value $<0.85$, between constructs there are differences (measurements) from one another empirically.

Table 1

Heterotrait-Monotrait Ratio (HTMT) Full Model

\begin{tabular}{|c|c|c|c|c|c|}
\hline & External Factors & Individual Factors & $\begin{array}{l}\text { Entrepreneurial } \\
\text { Competence }\end{array}$ & Cross Cultural Competence & $\begin{array}{l}\text { Cultural } \\
\text { Orientation } \\
\end{array}$ \\
\hline External Factors & - & & & & \\
\hline Individual Factors & 0.672 & & & & \\
\hline Entrepreneurial Competence & 0.579 & 0.745 & & & \\
\hline Cross Cultural Competence & 0.680 & 0.652 & 0.668 & & \\
\hline Cultural Orientation & 0.656 & 0.600 & 0.741 & 0.618 & - \\
\hline
\end{tabular}

Table 1 shows the discriminant validity according to the HTMT criteria $(<0.85)$. This implies that the HTMT criterion does not detect any collinearity among the latent constructs (multicollinearity) from the construction of external factors, individual factors, cultural orientation, cross-cultural competence and entrepreneurial competence.

Table 2

Internal Consistency Reliability (n=129) Full Model

\begin{tabular}{lll}
\hline & Cronbach's Alpha & Composite Reliability \\
\hline Entrepreneurial Competence & 0.919 & 0.926 \\
Cross Cultural Competence & 0.856 & 0.885 \\
Cultural Orientation & 0.887 & 0.903 \\
Individual Factors & 0.880 & 0.900 \\
External Factors & 0.779 & 0.839 \\
\hline
\end{tabular}


For internal consistency reliability, Based on Table 2, it is shown that the value of Cronbach's Alpha> 0.7 and composite reliability $>0.7$, thus, it can be explained that each latent variable in this study has good reliability.

\subsection{Inner Model Validation}

The results of the structural model test of this study are presented in Table 3.

Table 3

Structural Model Test Results for the Full Model

\begin{tabular}{|c|c|c|c|c|c|c|}
\hline & $R^{2}$ & $Q^{2}$ & GoF & & Path Coefficients & t-statistics \\
\hline \multirow[t]{2}{*}{ Cultural Orientation (CO) } & 0.369 & 0.855 & 0.521 & Individual Factors $\rightarrow \mathrm{CO}$ & 0.320 & 3.724 \\
\hline & & & & External Factors $\rightarrow \mathrm{CO}$ & 0.370 & 4.468 \\
\hline \multirow[t]{2}{*}{ Cross Cultural Competence (CC) } & 0.413 & & & Individual Factors $\rightarrow$ KLB & 0.382 & 3.855 \\
\hline & & & & External Factors $\rightarrow$ KLB & 0.348 & 3.043 \\
\hline \multirow{4}{*}{ Entrepreneurial Competence (EC) } & 0.610 & & & Individual Factors $\rightarrow$ EC & 0.379 & 5.428 \\
\hline & & & & External Factors $\rightarrow$ EC & -0.061 & 0.791 \\
\hline & & & & $\mathrm{CO} \rightarrow \mathrm{EC}$ & 0.420 & 5.906 \\
\hline & & & & $\mathrm{KLB} \rightarrow \mathrm{EC}$ & 0.174 & 2.493 \\
\hline
\end{tabular}

* Significant at $\propto=0.05(\mathrm{t}$ table $=1.97)$

Based on Table 3, it is known that the t-stat value for all has an effect except for external factors on entrepreneurial competence. These results indicate that there is a significant direct effect for all relationships, except for external factors on entrepreneurial competence. Furthermore, the Q-square value close to one indicates that the model has a relevant predictive value. The results of the Q-square calculation obtained a value of 0.855 . This means that it is closer to the value of 1 , and then the model is considered fit with a large interpretation. Meanwhile, to evaluate the PLS model, it is done by calculating the GoF. Based on the results of data processing, the GoF value was 0.521 . This indicates that the model of the study is fit.

\subsection{Hypothesis testing}

Based on the results of hypothesis testing, a summary table of the results of the research hypothesis is displayed as shown in Table 4.

Table 4

Hypothesis testing results

\begin{tabular}{|c|c|c|c|c|}
\hline \multirow[t]{2}{*}{ Hypothesis } & \multicolumn{4}{|c|}{ Competency Model of SME Entrepreneurs in Fashion $(n=129)$} \\
\hline & Estimation Coefficient & $\mathbf{R}^{2}$ & F-count $* \&$ t-count & Conclusion \\
\hline \multirow[t]{3}{*}{ Individual Factors and External Factors $\rightarrow$ Cultural Orientation } & & 0.369 & $36.842 *$ & Significant \\
\hline & 0.320 & & 3.724 & Significant \\
\hline & 0.370 & & 4.468 & Significant \\
\hline \multirow{3}{*}{$\begin{array}{l}\text { Individual Factors and External Factors } \rightarrow \text { Cross Cultural } \\
\text { Competence }\end{array}$} & & 0.413 & $44.325^{*}$ & Significant \\
\hline & 0.382 & & 3.855 & Significant \\
\hline & 0.348 & & 3.043 & Significant \\
\hline \multirow{3}{*}{$\begin{array}{l}\text { Individual Factors and External Factors } \rightarrow \text { Entrepreneurial } \\
\text { Competence }\end{array}$} & & 0.223 & $18.081^{*}$ & Significant \\
\hline & 0.379 & & 5.428 & Significant \\
\hline & -0.061 & & 0.791 & Not Significant \\
\hline \multirow{3}{*}{$\begin{array}{l}\text { Cultural Orientation and Cross-Cultural Competencies } \rightarrow \\
\text { Entrepreneurial Competence }\end{array}$} & & 0.387 & $39.773^{*}$ & Significant \\
\hline & 0.420 & & 5.906 & Significant \\
\hline & 0.174 & & 2.493 & Significant \\
\hline
\end{tabular}

\section{Discussion}

\subsection{The Influence of Individual Factors and External Factors on Cultural Orientation}

The influence between individual factors and external factors on cultural orientation with a determinant coefficient $\left(\mathrm{R}^{2}\right)$ of $36.9 \%$. Furthermore, the simultaneous test results obtained the value of F-stat.36,842> F-tab 3.07. This illustrates that the individual factors of entrepreneurs and the implementation of external factors influence the formation of their cultural orientation. Based on existing theories, some literature only examines relationships partially such as those that find a relationship between individual factors and cultural dimensions, while Inglehat and Baker (2000) provide evidence of a link between external factors such as economic development and cultural change. Whereas in this study the cultural orientation is influenced by individual factors and external factors together. Thus, the results of testing the effect of individual factors and external factors on cultural orientation simultaneously do not exist, so that the propositions and results of this hypothesis are novel in the field of management research. Furthermore, the partial test results of the influence of individual factors on cultural orientation obtained $\mathrm{t}$-stat. value 3,724> t-tab 1.97. This proves that there is an influence of individual factors on cultural orientation. The results of this study are in accordance with the opinion of Hofstede (2016) that found a relationship between Hofstede's cultural dimensions and personality dimensions (personality test results) even though the findings are 
statistical, and it is also concluded that national cultural values should not be used for individual stereotypes. Johnson et al., (2006) argued that a person's ability is strengthened by components such as cultural distance. This research can be a new finding and add to the literature reference which is currently still very few. While the partial test results of the influence of external factors on cultural orientation obtained the value of $t$-stat. 4.468 $>$ t-tab 1.97. This shows that external factors that occur around entrepreneurs contribute to shaping their cultural orientation. This is in accordance with the opinion of (Inglehat \& Baker, 2000).

\subsection{The Influence of Individual Factors and External Factors on Cross-Cultural Competence}

The influence of individual factors and external factors on cross-cultural competence with a determinant coefficient $\left(\mathrm{R}^{2}\right)$ of 41.3\%. Furthermore, the simultaneous test results obtained F-stat. 44,325> F-tab 3.07. This shows that the individual entrepreneur's factors together with the implementation of external factors play a role in shaping their cross-cultural abilities. The results of testing this hypothesis are in line with the findings of the concept of Johnson et al., (2006) which states that knowledge, Proficiency (abilities, talents) and personal attributes (values, beliefs, norms, personality traits) reinforced by moderation of various environmental variables such as language, economy, politics, legal systems and culture are the formers of cross-cultural competence in SME entrepreneurial activities. Furthermore, the partial test results of the influence of individual factors on cross-cultural competence obtained t-stat. value 3.855> t-tab 1.97. This proves that there is an influence of individual factors on cross-cultural competence. The individual quality of an entrepreneur determines the formation of his abilities across cultures. The results of this study are consistent with the findings of Johnson et al. (2006) in their conceptual study which developed a model of individual understanding (values) to be linked to the concept of cultural intelligence. The results of this study also support the findings of Harvey et al., (2012) which state that without understanding one's identity (self-concept), it is difficult to study the complexities of cross-cultural competences. While the partial test of the influence of external factors on cross-cultural competence, the score of t-stat. 3.0435>t-tab 1.97 was obtained. The partial test results between external factors and cross-cultural competence found that conditions outside of the entrepreneurs influenced the formation of their cross-cultural abilities. The results of this study are consistent with what Johnson et al., (2006) stated that in addition to the forming components that come from individuals, a person's cross-cultural abilities are strengthened by other components such as cultural distance.

\subsection{The Influence of Individual Factors and External Factors on Entrepreneurial Competence}

The influence of individual factors and external factors on entrepreneurial competence with a determinant coefficient $\left(\mathrm{R}^{2}\right)$ of $22.3 \%$. Furthermore, the simultaneous test results obtained the value of F-stat. 18.081> F-tab 3.07. These results indicate that the individual factors of entrepreneurship and the implementation of external factors have an impact on the formation of entrepreneurial competencies. Kaur \& Sandhu, (2014) stated that in entrepreneurship, external factors are difficult to control, so the role of individual factors is needed to overcome them. Unay \& Zehir (2012) argues that innovation is regulated by creative individuals and does not oCCur spontaneously. The role of entrepreneurs as individuals, their creativity, innovation, entrepreneurial and managerial aspects of the economy, will determine suCCess in global business competition. In addition, creative entrepreneurs have many entrepreneurial personality traits such as locus of control, innovation and achievement motivation, high tolerance for ambiguity, perseverance, independence, adaptability, autonomy, creativity and innovation (Protogerou et al., 2015; Astuty et al., 2021).

The partial test results of the influence of individual factors on entrepreneurial competence obtained t-stat. value of 5.428> $\mathrm{t}$-tab 1.97. This proves that individual factors have an effect on entrepreneurial competence. Human capital as a unique need for entrepreneurship is needed to gain entrepreneurial competence and there is a need for an open attitude towards SME entrepreneurs towards competency development in order to increase SME competitiveness (Man et al., 2002; Hayton \& Kelley, 2006; Ahmad, 2007; Lampel \& Germain, 2016). Furthermore, the partial test of the influence of external factors on entrepreneurial competence obtained the value of t-stat. $0.791>\mathrm{t}$-tab 1.97. This proves that external factors have no effect on entrepreneurial competence. This result is not in line with some literature such as the findings of Kollmann et al. (2007) who argue that entrepreneurial orientation is influenced by external factors and Kirzner (2009) argues about public policies that encourage entrepreneurial potential and Tambunan (2008) stated that the role of government is a very important external factor in supporting SME entrepreneurship in Indonesia.

\subsection{The Influence of Cultural Orientation and Cross-Cultural Competence on Entrepreneurial Competence}

The influence of cultural orientation and cross-cultural competence on entrepreneurial competence with a determinant coefficient (R2) of $38.7 \%$. Furthermore, the simultaneous test results obtained F-stat. 39,773> F-tab 3.07. This indicates that their cultural orientation and cross-cultural competences have an impact on the formation of their entrepreneurial abilities. The role of cultural orientation, cross-cultural ability and entrepreneurial competence can prepare entrepreneurs to run businesses in the international arena. Entrepreneurs who are able to manage risks in the global economy and can compete by having a cross-cultural orientation and competence will help them also in international business cooperation and can make them effective global leaders (Muzychenko, 2008; Cao, 2012; Caligiuri \& Tarique, 2012; Lee, 2018). 
The results of the partial test of the influence of cultural orientation on entrepreneurial competence obtained a t-stat. value of 5.906 $>$ t-tab 1.97. This proves that cultural orientation influences the formation of entrepreneurial competence for entrepreneurs. This is in line with the opinion of Rosillo-Díaz et al. (2019) that certain cultural tendencies in producing entrepreneurs have resulted in the determinants of entrepreneurship appearing to be influenced by culture and the opinion of Engelen et al. (2014) which suggests an insight into Thai and German culture, respectively, in which certain cultures have a greater influence on entrepreneurship than other cultures. Furthermore, the partial test results of the effect of cross-cultural competence on entrepreneurial competence obtained $t$-stat. value $2.493>t$-tab 1.97. This shows that there is a positive and significant direct effect of cross-cultural competence on entrepreneurial competence. The results of this study support the opinion of Muzychenko (2008); Knorr et al., (2013); Alvarez \& Urbano (2013) stated that to identify international opportunities, a strategy is needed that creates the cross-cultural capabilities of an entrepreneur in order to shape his entrepreneurial abilities.

\section{Conclusion}

Individual factors and external factors simultaneously and partially play a role in shaping the cultural orientation of entrepreneurs. In shaping their insights and thoughts, the role of external factors is bigger than individual factors. This shows that the drive of external conditions determines the need for the formation of a cultural orientation. Furthermore, individual factors and external factors have a role in forming cross-cultural competences, both jointly and partially. In this case, the quality of entrepreneurs has a greater role in shaping cross-cultural capabilities than the demands of external conditions. Next, individual factors and external factors together have a role in shaping entrepreneurial competence. However, only partially individual factors have a positive and significant role in shaping the entrepreneurial ability of each entrepreneur. Meanwhile, cultural orientation and cross-cultural competence have a significant role in shaping entrepreneurial competence. Both play a direct role in entrepreneurial skills in the global era. This shows that in doing business in international business, thinking and abilities from a cross-cultural perspective need to be present in every entrepreneur.

\section{References}

Abbey, A. (2002). Cross-cultural comparison of the motivation for entrepreneurship. Journal of Business and Entrepreneurship, 14(1), 69.

Ahmad, N. H. (2007). A cross cultural study of entrepreneurial competencies and entrepreneurial suCCess in SMEs in Australia and Malaysia (Doctoral dissertation).

Álvarez, C., \& Urbano, D. (2013). Cultural diversity and entrepreneurial activity [Diversidad cultural y emprendimiento].

Astuty, W., Pasaribu, F., Rahayu, S., \& Habibie, A. (2021). The influence of environmental uncertainty, organizational structure and distribution network competence on the quality of supply chain management information systems. Uncertain Supply Chain Management, 9(1), 116-124.

Bacigalupo, M., Kampylis, P., Punie, Y., \& Van den Brande, G. (2016). EntreComp: The entrepreneurship competence framework. Luxembourg: Publication Office of the European Union, 10, 593884.

Baum, J. R., Frese, M., Baron, R. A., \& Katz, J. A. (2007). Entrepreneurship as an area of psychology study: An introduction. The psychology of entrepreneurship, 1, 18.

Bukhori, A. (2021). The Role of Youth in Managing Educational Startup: Case Study of PrivatQ Startup. Research Horizon, 1(2), 62-70.

Caligiuri, P., \& Tarique, I. (2012). Dynamic cross-cultural competencies and global leadership effectiveness. Journal of world Business, 47(4), 612-622.

Engelen, A., Flatten, T. C., Thalmann, J., \& Brettel, M. (2014). The effect of organizational culture on entrepreneurial orientation: A comparison between Germany and Thailand. Journal of small business management, 52(4), $732-752$.

Harvey, M., Mcintyre, N., Moeller, M., \& Sloan III, H. (2012). Managerial self-concept in a global context: An integral component of cross-cultural competencies. Journal of Leadership \& Organizational Studies, 19(1), 115-125.

Hayton, J. C., \& Kelley, D. J. (2006). A competency-based framework for promoting corporate entrepreneurship. Human resource management: Published in cooperation with the School of Business Administration, The University of Michigan and in Alliance with the Society of Human Resources Management, 45(3), 407-427.

Hofstede, G. (2010). Geert hofstede. National cultural dimensions, 2-7.

Hofstede, G. (2016). Culture's consequences: Comparing values, behaviors, institutions, and organizations across nations. Collegiate Aviation Review, 34(2), 108.

Hull, C. E. K., Hung, Y. T. C., Hair, N., Perotti, V., \& DeMartino, R. (2007). Taking advantage of digital opportunities: a typology of digital entrepreneurship. International Journal of Networking and Virtual Organisations, 4(3), $290-303$.

Inglehart, R., \& Baker, W. E. (2000). Modernization, cultural change, and the persistence of traditional values. American sociological review, 19-51.

Johnson, J. P., Lenartowicz, T., \& Apud, S. (2006). Cross-cultural competence in international business: Toward a definition and a model. Journal of international business studies, 37(4), 525-543.

Kaur, S., \& Sandhu, M. S. (2014). Internationalisation of born global firms: Evidence from Malaysia. Journal of the Asia Pacific Economy, 19(1), 101-136. 
Khalid, S., \& Bhatti, K. (2015). Entrepreneurial competence in managing partnerships and partnership knowledge exchange: Impact on performance differences in export expansion stages. Journal of World Business, 50(3), 598-608.

Kirzner, I. M. (2009). The alert and creative entrepreneur: A clarification. Small Business Economics, 32(2), $145-152$.

Knörr, H., Alvarez, C., \& Urbano, D. (2013). Entrepreneurs or employees: a cross-cultural cognitive analysis. International Entrepreneurship and Management Journal, 9(2), 273-294.

Kollmann, T., Christofor, J., \& Kuckertz, A. (2007). Explaining individual entrepreneurial orientation: Conceptualisation of a cross-cultural research framework. International Journal of Entrepreneurship and Small Business, 4(3), $325-340$.

Lampel, J., \& Germain, O. (2016). Creative industries as hubs of new organizational and business practices.

Lampela, H., Taipale-Erävala, K., \& Heilmann, P. (2014). Growth through SME Business Model Innovations and Competence Changes. In ISPIM Conference Proceedings (p. 1). The International Society for Professional Innovation Management (ISPIM).

Lee, E. (2018). The cultural competency for working with Asian American clients scale: Development and validation. Research on Social Work Practice, 28(4), 463-474.

Man, T. W., Lau, T., \& Chan, K. F. (2002). The competitiveness of small and medium enterprises: A conceptualization with focus on entrepreneurial competencies. Journal of business venturing, 17(2), 123-142.

Muzychenko, O. (2008). Cross-cultural entrepreneurial competence in identifying international business opportunities. European Management Journal, 26(6), 366-377.

Naisbitt, J. (2006). Europe: Mutually Assured Decline. Mindset. Reset Your Thinking and See the Future.

Neneh, N. B., \& Vanzyl, J. (2012). Towards establishing long term surviving small and medium enterprises (SMEs) in South Africa: An entrepreneurial approach. African Journal of Business Management, 6(28), 8327-8343.

Protogerou, A., Caloghirou, Y., \& Markou, F. (2015, September). Entrepreneurial ventures in the creative industries: A case study approach. In 27th annual EAEPE conference 2015 (pp. 17-19).

Richter, N. F., Hauff, S., Schlaegel, C., Gudergan, S., Ringle, C. M., \& Gunkel, M. (2016). Using cultural archetypes in cross-cultural management studies. Journal of International Management, 22(1), 63-83.

Rosillo-Díaz, E., Blanco-Encomienda, F. J., \& Crespo-Almendros, E. (2019). A cross-cultural analysis of perceived product quality, perceived risk and purchase intention in e-commerce platforms. Journal of Enterprise Information Management.

Sadler-Smith, E., Hampson, Y., Chaston, I., \& Badger, B. (2003). Managerial behavior, entrepreneurial style, and small firm performance. Journal of small business management, 41(1), 47-67.

Sajilan, S., \& Tehseen, S. (2015). Cultural orientations, entrepreneurial competencies and SMEs business suCCess: The contingent roles of environmental turbulence and network competence. Review of Integrative Business and Economics Research, 4(2), 20.

Sajilan, S., Hadi, N. U., \& Tehseen, S. (2015). Impact of entrepreneur's demographic characteristics and personal characteristics on firm's performance under the mediating role of entrepreneur orientation. Review of integrative business and economics research, 4(2), 36.

Tambunan, T. (2008). SME development, economic growth, and government intervention in a developing country: The Indonesian story. Journal of international entrepreneurship, 6(4), 147-167.

Ulwan, A. N. (2021). The Role of Young Entrepreneurs in Labor Absorptions and its Implications to Family Economic Resilience. Research Horizon, 1(1), 16-27.

Ünay, F. G., \& Zehir, C. (2012). Innovation intelligence and entrepreneurship in the fashion industry. Procedia-Social and Behavioral Sciences, 41, 315-321.

Welter, F. (2011). Contextualizing entrepreneurship — conceptual challenges and ways forward. Entrepreneurship theory and Practice, 35(1), 165-184.

Yuhua, Z., \& Bayhaqi, A. (2013). SMEs' participation in global production chains. APEC PSU Issues Paper, 3. 
(C) 2022 by the authors; licensee Growing Science, Canada. This is an open access article distributed under the terms and conditions of the Creative Commons Attribution (CC-BY) license (http://creativecommons.org/licenses/by/4.0/). 